\title{
Anal Cancer pT0 TNM Finding v6 and v7
}

National Cancer Institute

\section{Source}

National Cancer Institute. Anal Cancer pTO TNM Finding v6 and v7. NCI Thesaurus. Code C67537.

Anal cancer with no evidence of a primary tumor. (from AJCC 6th and 7th Eds.) 